\title{
Nigeria: \\ Oil Exploitation and Conflict Transformation in Edo State
}

\author{
Samuel Osagie ODOBO
}

\begin{abstract}
The article is an extract from a broader empirical study conducted in 2015. It examined the dynamics of oil exploitation and conflict transformation in Edo State, Nigeria - an area often erroneously viewed as one of the zones of peace in Nigeria's turbulent Niger Delta region. The mixed method research was adopted. Using content analysis and descriptive statistics, the paper argued that oil-induced conflicts in Edo State are embedded in the narrative of grievances, poverty, absence of development, suppression and perceived neglect by government and oil companies. These issues have been addressed largely through the use of force, selective dialogue, suppression and infiltration of activism. Conflict transformation requires addressing the underlying causes of the conflict and building long-standing relationship through a process of change in perception and attitude of stakeholders. Beyond remediation of the environment, resource-rich communities in Nigeria yearn for infrastructural and human capital development both of which have remained elusive. Addressing community demands require confidence building, robust engagement and active local participation in community development and peacebuilding initiatives.
\end{abstract}

Keywords: Oil exploitation, conflicts, conflict transformation, Edo state, Nigeria.

\section{Introduction}

Studies on oil and conflicts in Nigeria abound (Bassey, 2012; Clark, 2016; Adeosun, Norafidah and Zengeni, 2016). What seems to be the general consensus in these studies is that despite the fact that oil remains the backbone of Nigeria's economy, yet its exploitation has not translated into any tangible socio-economic benefits in the Niger Delta region, where the bulk of the oil is extracted. The puzzling inability of the
Samuel Osagie ODOBO

Institute for Peace \& Strategic Studies,

University of Ibadan, Nigeria

Email: soodobo@yahoo.com

Conflict Studies Quarterly

Issue 22, January 2018, pp. 62-80

DOI:10.24193/csq.22.4

Published First Online: 01/10/2018 
Nigerian state to utilize oil revenue to drive economic growth and development validates the resource curse hypothesis and the massive environmental degradation and sundry social deprivations in the Niger Delta have triggered and exacerbated a complex mix of multi-dimensional oil-induced conflicts in the region. Within the last two decades, a swarm of violent armed groups emerged and clashed intermittently with security forces, vandalized oil installations, carried out lethal bombing of civilian and non-civilian targets alike, taken foreign and local oil workers hostage and initiated a culture of kidnapping for ransom that has now become a major national security problem in Nigeria.

Efforts to manage the crisis through non-adversarial modes of conflict management, such as the amnesty initiative and development interventions, have not had the expected impact on the socio-economic conditions of the people of the region, while adversarial strong-arm tactics also backfired in most cases. Consequently, the Niger Delta area remains one of the most volatile regions in Nigeria and home to several armed groups such as the Movement for the Emancipation of the Niger Delta (MEND), the Niger Delta Avengers (NDA), Niger Delta Revolutionary Crusaders, Reformed Egbesu Boys of the Niger Delta, the Niger Delta Greenland Justice Mandate and AdakaBoro Avengers. Although the magnitude and impacts of activism vary, local grievances are similar in core and fringe Niger Delta areas. The activities of these groups have, over time, attracted significant negative socio-economic and political consequences for the nation.

Edo State, by classification, is a fringe state in the Niger Delta, along with Abia, Akwa Ibom, Cross River, Imo and Ondo. It has had its fair share of oil-induced conflicts. However, the dynamics of these conflicts and how they are managed hardly feature in the analyses of oil and conflicts in the Niger Delta which have largely focused on the core Niger Delta states of Bayelsa, Delta and Rivers which are the main conflict theatres in the region. Oil was first discovered in Edo State in 1967 but actual production only began in the early 1970s. Oil is present and exploited in three local government areas in the state: Orhionmwon, Ikpoba-Okha and Ovia North East. Like their counterparts in core Niger Delta states, oil-bearing communities in the state have experienced problems associated with oil exploitation.

\section{Guiding Theory: Conflict Transformation}

Conflict transformation has been used enormously in the place of conflict management because they are thought to have overlapping meanings. However, while conflict management aims to regulate and contain conflict without necessarily ending it, transformation involves reframing the positions, social structures and underlying factors that gave rise to the conflict in the first place (Paffenholz, 2009). It is the argument of conflict management theorists that conflict is a consequence of competing values and interests within and between groups (Debraj \& Esteban, 2017). Such conflicts can 
be managed or contained through compromises that put the conflict aside and allow peaceful relationship to thrive (Paffenholz, 2009).

Conflict transformation recommends that beyond containment, conflicts can be transformed into positive peacebuilding. Lederach (1997) developed one of the most authoritative and widely discussed transformation-focused conflict intervention approaches. It is his view that conflicts can be transformed in the long term by gradually altering perceptions of issues, actions and the conflict actors. Since conflict usually transforms perceptions by accentuating incompatibilities and differences between people and positions, effective conflict transformation will focus on improving mutual understanding of interests, values and needs and how these are pursued. Accordingly, it also involves transforming the way conflict is expressed. It may be expressed competitively, aggressively, or violently, or it may be expressed through nonviolent means such as conciliation, cooperation or joint problem solving.

Conflict transformation focuses on four key areas: actor transformation, issue transformation, rule transformation and structural transformation. It is the goal of conflict transformation to cause positive change in the fundamental relationships among stakeholders beyond merely containing the conflict. Perhaps, the largest contribution of the conflict transformation school is its focus on local community participation in decision-making in the process of peacebuilding, as well as the insistence on addressing the underlying causes of conflicts because transformation cannot take place until the root causes of conflicts and the structures that support violence are removed and conscious efforts instituted to restore and facilitate positive stakeholder relationships.

\section{Literature Review: 0il Exploitation and Conflict Transformation in Nigeria}

A significant number of studies on causes of conflicts in the Niger Delta hinge their arguments on Collier and Hoeffler's (2004) greed-grievance hypothesis. A general belief is that negative ecological impact of oil exploitation that affects the economic base of local communities is a primary cause of oil-induced conflicts in the Niger Delta area (Clark, 2016; Shebbs \& Njoku, 2016). These studies argue that after decades of oil exploitation, the Niger Delta environment had become devastated to the extent that preexisting patterns of production in the local communities have become irreparably altered. Failure of the Nigerian state and multinational oil companies to address associated problems eventually elicited violent response from the local population.

In his analysis of the political economy of resource conflicts, Ikelegbe (2005) noted that grievance can quickly transform into greed. Although oil-related conflicts could be driven by grievances, the motivation to sustain the conflict may be driven by a desire to exploit the situation for private gains, especially where the actors (state and non-state) benefit directly or indirectly from the conflict. It can be argued, therefore, that while 
oil conflicts in the Niger Delta area were not originally driven by greed, it appeared at some point to have become the reason for sustaining the conflicts. For Joab-Peterside, Porter and Watts (2012), state officials, security agents, politicians, armed groups and others have become major actors and conflict entrepreneurs in the Niger Delta because there were gains to be made thereby.

The unhealthy competition for crude oil and control of oil rents, which has been a permanent feature in stakeholders' relationship in Nigeria's weakened nation-building, led to the decline of other productive sectors of the nation's economy and increased the struggle for political power in a desperate bid to control oil revenue (Siollun, 2009). Thus, oil presence not only became an impediment to democratic development, it also incentivized and sustained military incursion into politics and plunged Nigeria deep into protracted conflicts starting with the civil war that raged between 1967 and 1970 . Furthermore, oil wealth eroded fiscal federalism and replaced it with fiscal centralism and in the process eroded regional autonomy and resource control.

The new political arrangement robbed the southern minority areas of the Niger Delta of the control over the oil revenue. Instead, what the region gets is a meagre derivation token which barely compensates for the ecological devastation and the other negative externalities of oil exploitation in the region. Thus, the question of ownership of oil resources or any resource for that matter remains a major trigger of tumults in the Niger Delta region. Added to these are the issues of compensation and poor remediation for environmental problems associated with oil exploitation and the much criticized halfhearted measures to develop the oil-bearing communities.

The question of compensation is, perhaps, the most cited reason for the intractability of conflicts across the Niger Delta region. Dissatisfaction of oil-bearing communities with compensation payments by oil companies and the government rests largely with the failure of the government to understand local perspectives on compensation that sustain the conflict and the reason why the people are up in arms against both the Nigerian state and the multinational oil companies. Ibeanu (2000) refers to this as the contradiction of security which the Nigerian government and the oil multinationals are unable to manage. For the local people, security implies recognition that reckless exploitation of crude oil and the resultant negative externalities threaten and even obliterate their livelihoods. Meanwhile, for the government and the oil companies, security means uninterrupted exploitation of crude oil irrespective of environmental and social impacts.

This preoccupation with unfettered extraction of crude oil partly explains the strongarm tactics employed by the state and the oil companies against local communities whenever they agitate. Studies by Human Rights Watch (1999), Faleti (2010), Bassey (2012) and a host of others have discussed extensively the repressive tactics of the government against popular mobilizations in the Niger Delta region. They tend to agree on this tactic having failed to address the core issues in the conflict, only succeeding in 
escalating the dysfunctional relationships in the region. As Bassey (2012) noted, youths in oil-bearing communities were radicalized by the government's repressive tactics and their response came in the form of attacks against oil facilities and infrastructures with serious consequences forboth the nation and oil firms.

Apart from the adversarial strategy adopted by the government and oil multinationals combined, another approach adopted by the government included the establishment of interventionist agencies to drive development in the region. Beginning with the Niger Delta Development Board (NDDB) in 1961, Niger Delta Basin Development Authority (NDBDA) in 1976, the Oil Minerals Producing Areas Development Commission (OMPADEC) in 1992, the Niger Delta Development Commission (NDDC) in 2001, to the Ministry of Niger Delta Affairs in 2008, the government tried to address the infrastructural and human capital development deficits in the Niger Delta. However, the lack of political commitment to energize the development agencies, funding issues, political interference and lack of autonomy were problems that plagued these interventionist bodies. Other problems included accountability and transparency deficits, massive official corruption and non-involvement of the local communities whose interests they were designed to serve (Emuedo, 2015).

At the level of corporate efforts to address the dysfunctional relationships in the region, Faleti (2010) examined development initiatives by oil multinationals who were focused on procuring a license to operate and douse tensions in the host communities across the Niger Delta. The central argument in the study is that oil companies operating in the region were initially reluctant to give back to the communities where they operated chiefly because they deemed that their responsibility was limited to paying taxes and remaining law abiding. As community agitations mounted, oil companies deployed all manners of tactics including 'divide and rule' that set individuals and groups within host communities against each other while friendly community leaders were rewarded with lucrative contracts and other perks including paid holidays and medical trips abroad. The recalcitrant and activist-minded were given short shrift and were likely to be targeted by security agents.

Aiyede (2006) and Idemudia (2009a) similarly commented on how this adversarial conflict management strategy worked until the 1990s when it came under increasing attacks from communities, human rights and environmental activists. Community leaders who were deemed to have compromised were roundly branded as traitors. The negative publicity that the government's strong arm tactics and multinational oil companies' unethical practices attracted, became major motivations that compelled both the Nigeria government and multinational oil companies to rethink their relationships with local communities.

Consequently, oil companies reframed their community engagement approaches by providing social infrastructures such as roads, electricity, health care, borehole water 
supply, scholarship programmes, employment of indigenes from host communities and other forms of community support programmes. The government also adopted a softer approach to communities' agitations. Notwithstanding, oil companies CSR initiatives have roundly been criticized for lacking adequate community participation in the planning, implementation and execution of community assistance projects, as well as accusations of selective patronages (Emuedo, 2015). The sort of privileged status that selective patronage confers on a few individuals within the community creates fragmentation and dislocation of social cohesion in the community. Community leaders and youths who benefit directly from patronage networks created by their association with the oil companies, use the medium to accumulate wealth,as funds that are earmarked for community development are diverted for personal use (Faleti, 2010).

Failure of these conflict management styles to work on the multidimensional conflicts in oil-bearing communities meant that the conflict remained largely intractable. Added to this was the emergence of new and more violent conflicts with crippling impact on the Nigerian economy. The failure of the military forces to diffuse conflict, especially militancy in the Niger Delta, made former President Yar'Aduainitiate a conditional offer of amnesty to militants in 2009 in return for peace. The 2009 amnesty initiative had three components. The first was disarmament of members of the armed groups who were expected to turn in their weapons and complete the requisite form of renunciation of violence. The second stage involved rehabilitation and reintegration of demobilized militants, including the payment of stipends. The third covered the post-amnesty package of massive infrastructural development.

The amnesty programme helped in dousing tension in the Niger Delta area. It brought about improvement in oil production and revenues, fewer deaths and hostage taking. However, it failed to address the third phase of the programme - socio-economic development of the region. The deep-rooted causes of conflict in the region, such as poverty, high youth unemployment, underdevelopment, inequality, local economy dysfunction, official corruption and continued environmental degradation, have remained unresolved (Ikelegbe \& Umukoro, 2014). The amnesty process was not only corrupt and unsustainable, but it also promoted warlordism and the spread of organized crime among other things (Sayne, 2013). The particular focus on (ex) militants made the amnesty initiative difficult to view as part of a larger Niger Delta peace plan. Hence, it amounted to a mere attempt by the Nigerian government to buy short-term ceasefire (Newsom, 2011).

\section{Scope and Methodology}

The study focused on six selected oil-bearing communities of Edo State: Oben, Ologbo, Iguelaba, Ughoton, Gelegele and Obagie-Nokenkporo. It examined oil exploitation and conflict dynamics in the area. The study reviewed the strategies for conflict management and transformation. A combination of qualitative and quantitative methods was 
adopted. Oral interviews were conducted with traditional rulers, community leaders, youths and women leaders, staff members of oil companies and government oil commissions and civil society organizations. The interviews were complemented with a sample survey of 400 respondents across the six selected communities. The observation method was also utilized. Data collected through sample survey was analysed using simple descriptive statistics while the qualitative data were content-analysed.

\section{Oil and Conflict in Edo State}

Local agitations against oil companies were not obvious until the late 1990s and early 2000s. Host communities' agitations in Edo State were triggered by the rebellions of oil-bearing communities in other Niger Delta states, especially the core oil states of Delta, Bayelsa and Rivers. Agitations and militancy in these states had a mirror effect on the oil-bearing communities in Edo State, as the local populations became more conscious of the negative externalities of oil exploitation and the fact that they were being cheated by the government and oil companies who exploited the resource without corresponding benefits for the communities where the resource is located.

Furthermore, while ecological degradation due to exploitation of oil is often advanced as the main source of oil-related conflicts in the Niger Delta, the field survey of the studied communities indicated that it is not the most important conflict issue. Inadequate compensation, neglect by oil companies and neglect by the state constituted the central causes of conflict.

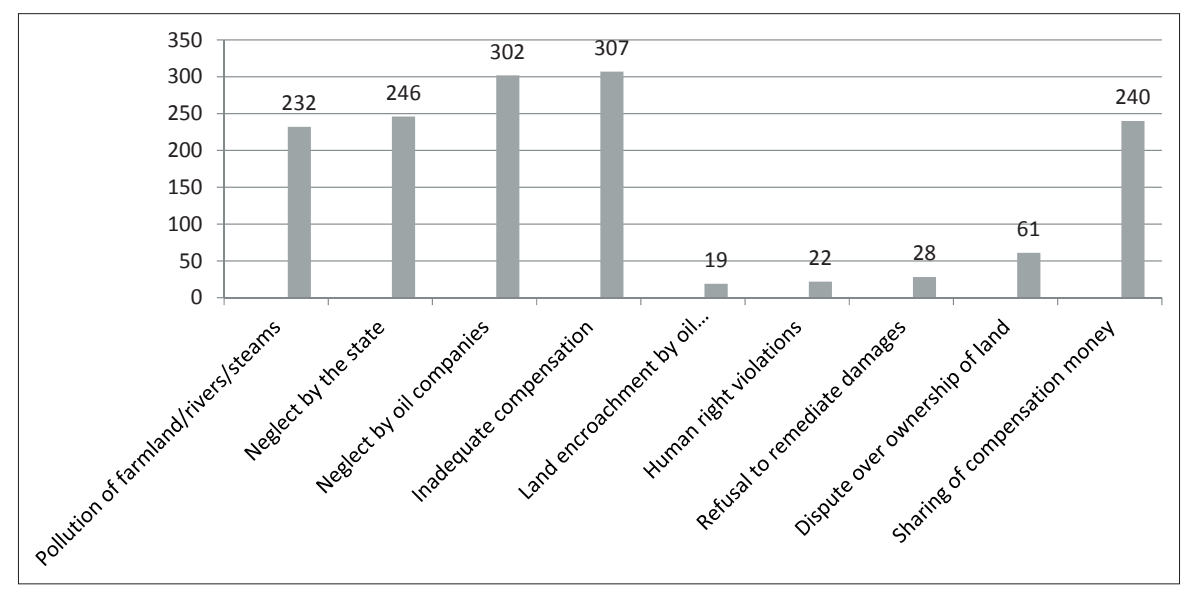

Fig. 1: Specific conflict issues in the communities

Source: Fieldwork report, 2015

The conflict issues arising from the exploitation of oil are linked together in a complex way and involve several stakeholders, including the youths, traditional rulers, commu- 
nity leaders, the state, oil commissions, oil companies, women and other social actors. While the youths are the most active players in the conflicts, other key actors exist. These include traditional rulers, community leaders, the oil companies and security forces. These actors are simultaneously involved in a number of these conflicts, and different forms of conflicts often feed off each other. The levels of conflict may be classified into four, though in practice, it is difficult to draw a clear line of distinction among them.

Table 1: Conflict Issues and Key Stakeholders

\begin{tabular}{|c|c|c|}
\hline Levels of Conflicts & Key Stakeholders & Conflict Issues \\
\hline ommunal & $\begin{array}{l}\text { traditional rulers, community leaders, } \\
\text { youths, community development asso- } \\
\text { ciations }\end{array}$ & $\begin{array}{l}\text { leadership struggle, mismanagement of com- } \\
\text { munity funds, sharing of employment slots, local } \\
\text { contracts }\end{array}$ \\
\hline Inter-Communal & $\begin{array}{l}\text { traditional/community leaders youth } \\
\text { groups }\end{array}$ & $\begin{array}{l}\text { land, power struggle, oil patronages, host com- } \\
\text { munity status, local economy buoyed by oil } \\
\text { presence and control }\end{array}$ \\
\hline $\begin{array}{l}\text { Oil Community vs. } \\
\text { Oil Companies }\end{array}$ & $\begin{array}{l}\text { traditional rulers, community leaders, } \\
\text { community development associations, } \\
\text { youth groups, civil society actors }\end{array}$ & $\begin{array}{l}\text { oil rents/rights, compensation, physical develop- } \\
\text { ment, employment, remediation of the environ- } \\
\text { ment, preference for "outsider" contractors for } \\
\text { lucrative jobs }\end{array}$ \\
\hline $\begin{array}{l}\text { Oil Community vs. } \\
\text { Government }\end{array}$ & $\begin{array}{l}\text { traditional rulers, community leaders, } \\
\text { youth groups, civil society actors, com- } \\
\text { munity development association }\end{array}$ & $\begin{array}{l}\text { government neglect, infrastructural deficits, un- } \\
\text { employment, oil rights, participation in extractive } \\
\text { activities }\end{array}$ \\
\hline
\end{tabular}

Source: Field report, 2015

Intra-Communal Conflicts: The key issues in intra-community conflicts are leadership struggles, embezzlement/mismanagement (real or imagined) of community development funds by community leaders, sharing of employment slots, local contracts and so on. Intra-communal conflicts are often over power and control of oil benefits. They involve struggle over community resources and disagreement among different community factions over how resources should be shared or managed. The issues in contention usually include composition of community representative bodies, how to utilize development funds, who gets contracts to execute community projects or has access to, or controls compensation money paid to the community by the oil companies. Sometimes, the disagreement involves low-level violence, as conflict parties mobilize support especially from among youth groups in their struggle for control of oil benefits. Watts (2004) labels these sorts of intra-communal feuds as struggle for "governable spaces" where the local elite scuffle to position themselves as intermediaries between the oil companies and the community.

Inter-Communal Conflicts: Inter-communal conflicts are mainly competition for "host community status," which confers some level of access to oil benefits, such as compensation, development projects, employment slots as well as struggle over oil-rich land. 
The attraction of host community status pitted Oben against neighbouring communities of Iguelaba, Ikobi and Obozogbe. In fact, the Bini-Ijaw conflict over Gelegele community assumed prominence as a result of discovery of oil wells in the area. According to Ofunama (personal communication, September 5, 2015),

They (Bini in Ughoton) have been laying claim of ownership over our land because of the oil and this has been causing problem. Oil is the main issue. The word "Edo State" should not be used to victimize settlers. They are hiding under the guise to say since Gelegele is under Edo State. It has caused a lot of problems.

For decades, the Bini of Ughoton and Ijaw of Gelegele have continued to feud over ownership of Gelegele. The two ethnic groups were peaceful neighbors before oil was discovered in the area. The presence of oil led to claims and counter-claims over who owned Gelegele. It also brought the settler/indigene question to the front burner of politics in Edo State.

Oil Communities versus Oil Companies: Conflicts emerged primarily from failure or reluctance of the oil companies to meet the key demands of the communities. These demands include compensation for occupied land or exploitation of their resources, development projects, employment, contracts and greater access to participate in the oil industry.

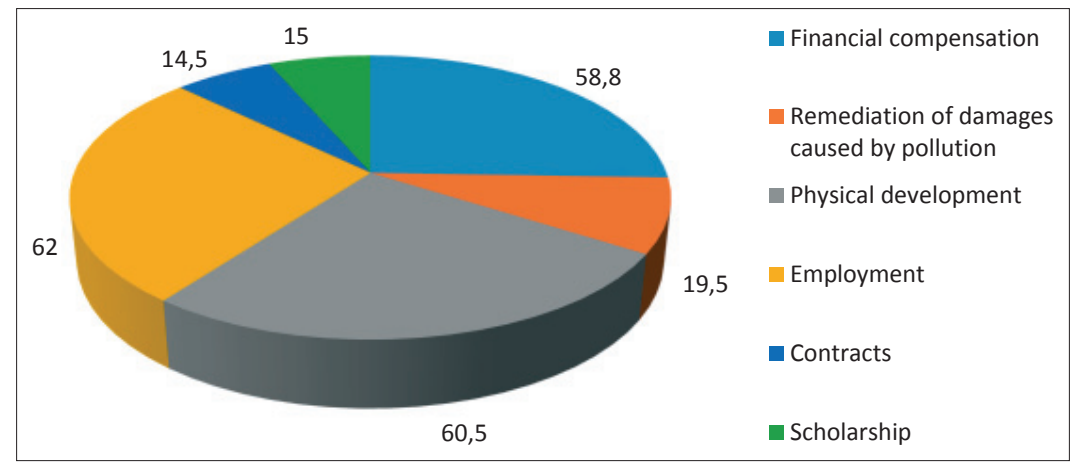

Fig 2: Key demands of oil-bearing communities

Source: Field report, 2015

Oil companies considered the provisions of some community demands, such as road construction and electrification projects, as unrealistic because they argued that it is the primary duty of government to meet such demands. Hence, the companies viewed their development interventions as complementary to government efforts and not assumption of the role of government. Ineffective communication or inadequate engagement between the companies and community representative usually resulted in strained relationships. 
Ecological impact of oil exploitation activities created further conflict. The altering of preexisting livelihood patterns compelled the local population to direct their attention towards securing increased local participation in the petroleum business and maximizing their benefits from oil exploitation.

Furthermore, the relationship between the oil-bearing communities and the oil companies is often characterized by suspicion and lack of trust. The local populations often accused the oil companies of using infiltration tactics to destabilize community harmony and prevent the local population from mustering an organized and united front against the companies. Aiyede (2006) notes that Shell and the other oil majors deliberately pursued divide-and-rule tactics that set individuals, groups and local communities against one another in the Niger Delta instead of fighting the "common enemies" which were the oil companies.

Ogiemwonyi (personal communication, September 24, 2015) noted that discontent of the local community in Obenagainst the oil companies partly emanated from their tendency to always use divide-and-rule tactics to manipulate local interest groups so as to avoid their corporate social responsibilities and/or meeting other commitments and promises made to the community. Instead of working with the community to address their needs, the companies often resorted to buying the cooperation of a few community leaders who were, in turn, mobilized to suppress community protest. Nevertheless, this strategy failed to achieve the desired result in Oben. Rather, it only created more problems within the community, which affected the oil company. Of note was the 2005 community youth protest which resulted in a temporary shutdown of the gas plant located at Shell's flow station in the community.

Oil Communities versus the Government: The main conflict issue between the local communities and the government is what the local people called "utter neglect" of oil communities by the government at all levels-federal, state and local. However, much of the blame is directed at the Federal Government which the local population accused of marginalizing the oil-bearing communities. The oil communities constitute a minority even within Edo State. Their main grievances with the government include the poor state of development and the very low level of government presence when compared to other oil-bearing communities in the core Niger Delta states where militancy is rife. They also criticized the contradiction of excruciating poverty in the communities against tremendous wealth being flagrantly displayed by government officials and staff members of government oil commissions who are supposed to cater for the needs of the oil-bearing communities.

These grievances are compounded by government's use of repression and suppression tactics. Attempts by the local populations to demand for what they considered as their "fair share" of oil benefits have, sometimes, been met with force by the police, soldiers and other government security agencies. However, unlike in the core Niger Delta states 
where these issues have triggered violent confrontations, leading to loss of lives and property, militancy, hostage taking, kidnapping and attacks on oil installations, conflicts between oil-bearing communities and the government in the studied communities were largely low-intensity conflicts, involving less violence.

\section{Strategies for Conflict Management and Transformation}

Managing Intra-Communal Conflicts: Dealing with intra-communal conflicts arising from oil exploitation was essentially the responsibility of the community development association (CDA) and the traditional elders' council (TEC). The TEC headed by the Enogie or Odionwere (traditional head) provided overall leadership in the oil-bearing communities. The CDA was not only empowered by the traditional elders' council to negotiate with the oil companies on matters of community needs, but also the body, in agreement with the TEC, was responsible for dealing with issues of compensation sharing, allocation of job slots and the management of community development funds. Essentially, the CDA framework provided some form of coherence and local participation in decision-making and management of oil benefits in the community. As Corwall, (2006) noted, the framework could be viewed as an important conflict management tool and development strategy since it provided some sort of community coherence in articulating its needs and the strategies for meeting such needs, including attracting development to the community.

However, poor gender representation in the composition of the CDA leadership constituted a problem to effectiveness of the CDA. Omorodion (personal communication, September 7 and 9,2015) observed that though women associations existed within the communities, they were hardly members of such community representative bodies and were never part of the team that often interfaced with the management of oil companies or had a say in the management of compensation money. Poor leadership, lack of transparency and issues of favouritism were other significant issues in the management of intra-communal conflicts. Minister (2015) claimed that community leadership often hijacked the process to attract self-development projects rather than community development projects. In fact, the allure of having access to large community funds, local contracts from the oil companies and other benefits made election/selection of leadership of most community development associations very competitive, secretive and sometime involving violence.

Omoregie (personal communication, September 23, 2015) averred that even Enogies and Odionweres occasionally became parties to the conflicts rather than managers of such. In Iguelaba and Ughoton, the Odionwere and Ohen (priest) got enmeshed in a dispute over who was the authentic head of the community. As the crisis escalated in Iguelaba, factions emerged in what transformed into a bloody conflict where youths were mobilized by both the Odionwere and Ohen factions. Such leadership struggles 
complicated the ability of the TEC or the CDA to manage emergent oil-related conflicts in the communities. Disputes involving community leadership were usually resolved either through litigation or conciliated by the palace of the Benin monarch, the Oba of Benin. Since the Enogie, Odionwere and Ohen were appointees of the Oba, the Oba gave the final verdict on the rightful head of the community.

Managing Inter-Communal Conflicts: Verbal threats, demonstrations and low-scale violence often characterized disputes between feuding communities. The initial response of communities especially to a contested oil-rich area was always confrontational. Communities laying claim to a particular area where an oil well was located, for example, oftentimes tended to use force to intimidate the other parties. This strategy always threatened to escalate tensions between the communities. The usual pattern was for the community leadership to mobilize demonstrations across the community stating their claim to the contested land area or the community's right to benefits coming from the oil companies. In an attempt by Ughoton to implement a Supreme Court judgment on land demarcation around a contested oil-rich area with Gelegele, Ughoton and Evborokho community leaders became embroiled in a clash that resulted in injuries.

Similarly, the Bini and Urhobo engaged in violent confrontations over a disputed oil well in Ukpakele. The dispute effectively prevented Pan Ocean Oil Company from engaging in drilling activities in the area. The Oba of Benin intervened in the dispute, declaring that the disputed area belonged to the Bini. Consequently, the Oba sent representatives to the area to install an Okao (traditional head) in the community. The Urhobo rejected the Oba's decision, refusing the Okao entry into the community. This approach heightened tension and insecurity in the area, affecting other spheres of the community, including businesses and schools being shut down for fear of attacks.

One approach that warring communities engaged in managing oil-related dispute was the adoption of intercommunity representative committee (IRC). Considering the fact that some of the underlying issues in intercommunity disputes were basically intense struggles for oil benefits, these communities were encouraged mainly by the oil companies to establish IRC, otherwise known as steering committee. The framework could be viewed as a corporate-community relation strategy (Idemudia, 2009a). It entailed a group of oil-bearing communities establishing a steering committee made up of representatives from each community to interface with the oil companies on matters of common interest. The mechanism also articulated modalities for sharing oil benefits amongst the cooperating communities.

The IRC mechanism achieved modest success in managing oil-related disputes between communities making up Oben Oilfield (Oben, Iguelaba, Ikobi and Obozogbe). It was particularly useful in sharing employment slots, development projects, "homages" and other financial rewards amongst the four communities. It was also useful in reducing inter-community/interethnic hostilities among oil-bearing communities making up 
Ologbo Dukedom, which are Imasabor, Oghobaye, Ologbo Central, and Itsekiri Waterside. Particularly, the framework significantly reduced the frequent agitations by the Itsekiri who complained of marginalization in the sharing of royalties and other largesse that came from the oil companies (Minister, 2015).

Although the IRC reflected some form of intercommunity peacebuilding measures and achieved, to some extent, community commitment to participatory partnership, there were still running battles and competitions among communities. Lack of trust was the biggest setback for the mechanism. Communities frequently accused one another of trying to sideline the others by going behind to negotiate with the oil companies. The oil companies were also accused of deliberately favouring some communities over others which went against agreed principles in the IRC arrangement. For example, the respondents in Iguelaba claimed that Oben continued to enjoy greater benefits from Seplat despite existing agreement that all four communities must share all oil benefits equally. Osakue (personal communication, September 8, 2015) noted also that the location of Dubril's flow station in Gelegele meant that the community attracted more development projects and other benefits than Ughoton and other communities in the area. Trust, accountability and transparency were some of the reasons Idemudia (2009b) argued that the extent to which the IRC approach have been able to engender effective intercommunity relations remains questionable.

Managing Conflicts between Oil Communities and Oil Companies: Initial disposition of oil communities towards the oil companies over the negative effects of exploitation activities on the communities was largely pacifist (Emuedo, 2015). Recourse to protest was indicative of the insensitivity and unwillingness of the oil companies to address fundamental issues raised by the communities. Effects of these protest, coupled with international criticism against the oil companies, forced the companies to adopt corporate social responsibility (CSR) initiatives as a mechanism for managing corporatehost community relations in the Niger Delta. CSR initiatives were basically targeted at addressing local grievances, community development, improved livelihood, conflict reduction and "freedom" to operate in the community.

The CSR initiatives of the oil companies in the Niger Delta have evolved over time from community assistance to community development and then, sustainable community development through corporate-community partnership (Faleti, 2010; Idemudia, 2011). In the studied communities, what was most visible in terms of CSR practices was a combination of philanthropy, social investment and stakeholder engagement. The oil companies engaged community representatives primarily on quarterly basis to discuss community needs and address potential threats to mutual coexistence between them and the community. Part of the process involved needs identification and agreeing on modalities to meet these needs. Oil companies social investment programmes often come in the form of community development projects, such as construction or renova- 
tion of classrooms, healthcare facilities and roads; provision of pipe-borne water and electricity; equipping school laboratories; provision of employment and scholarship programmes for the youths as well as women empowerment scheme. Some of these development projects, such as the teachers' quarters built in Oben and Iguelaba, the cottage hospitals in Oben and Gelegele, water scheme and electricity project in Gelegele and Ughoton were considerably successful in meeting specific needs of the local population.

However, proliferation of unnecessary projects, lack of community participation, problems of project sustainability and the tendency for community development projects to incite intra-and inter-communal conflicts were identified as some of the problems associated with the oil companies' CSR initiatives in the area. Ogiemwonyi (personal communication, September 24, 2015) is of the view that oil companies have never been genuinely committed to addressing the real development issues of oil-bearing communities. Rather, their community engagement initiatives are basically designed to satisfy selected individuals within the community who posed considerable threats to their operations. Ogiemwonyi's argument is consistent with the assertion of Carr and Snyder (2002) who describe such corporate crisis management response as one that basically recognizes the existence of threats, determines their consequences and mainstreams responses to mitigate their adverse consequences.

CSR responses that deliberately target or benefit only a particular set of individuals rather than the entire community could be viewed as a form of infiltration tactics. The implication is that it not only denies the community benefits that are commensurate with perceived value of the resources being exploited in the community. It also implies the unfortunate incorporation of the so-called cabals that have been settled into the crisis management or mitigation strategy of the oil companies. Minister (2015) captured the sort of relationship that exists between these influential individuals and the oil companies thus:

They are part of the oil company's management strategy. Once the leaders are settled, the issue is over and that is how they ensure everybody keeps quiet in the community. These stakeholders are employed by the oil companies to ensure there are no disturbances to their operations.

Thus, though this strategy contributed to dousing tension within oil-bearing communities, they stoked the embers of frustration and animosity among the local population towards such community leaders perceived to have compromised community interest in return for personal gains by yielding to the interests of the oil companies. Thus, community grievances against the oil companies have continued unabated despite the community development initiatives of the oil companies.

Managing Conflicts between Oil Communities and the Government: Oil community responses to perceived government neglect have largely involved agitations through town 
hall/community meetings, written petitions to government, sending delegations to government oil commissions, street demonstrations, mounting roadblocks and occasional interruption of the activities of oil companies. Conversely, it appears government mainly perceived community agitations especially those that interrupted oil extraction in any form as rebellion and acts of economic sabotage considering the strategic importance of crude oil to the nation's economy. Perhaps, this explains government's proclivity to deployment of state coercive apparatuses whenever it perceives a threat to crude oil exploitation. Thus, government's management style, as Okoh (2005) observed, has been one of containing or controlling the conflict mainly through coercive measures. This is in tandem with survey results on the perception of the respondents on how government has managed oil-induced conflicts in the study area.

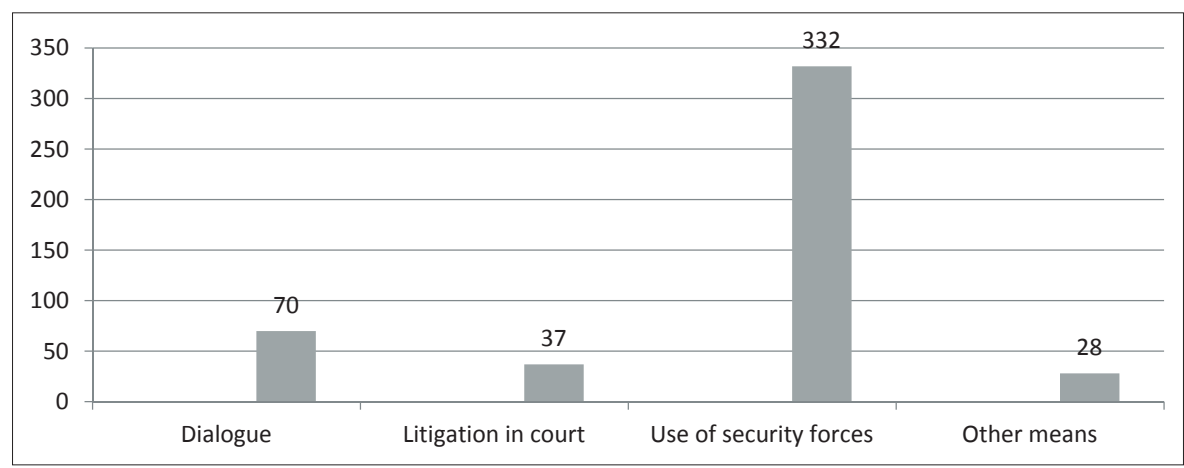

Fig. 3: Perception on government's conflict management strategies

Source: Fieldwork report, 2015

Besides the use of force, however, government also pursued non-adversarial measures of conflict management. These involved peace talks and town hall meetings organized by government agencies in collaboration with the oil companies, civil society organizations, and other different groups aimed at building peace between the government, oil companies and the communities. Such peace meetings resulted in the payment of compensation to communities for ecological degradation, investment in socio-economic infrastructures, scholarship and skill-acquisition programmes for youths, provision of soft loans, subsidies and other empowerment programmes for the women. It was also within this framework that the derivation principle grew from $3 \%$ to $13 \%$, thus increasing the revenue shared to the Niger Delta states. A corollary of this approach was the establishment of interventionist agencies to cater for the development needs of the oil communities. The Niger Delta Development Commission (NDDC) and Ministry of Niger Delta Affairs play this role at the federal level. Edo State Oil and Gas Producing Areas Development Commission (EDSOGPADEC) is a creation of Edo State Government mandated to bring development to the oil-bearing areas of the state. 
Some of the projects executed by the NDDC in the selected oil-bearing communities included building or renovation of classrooms, provision of electricity transformers, health centres and dispensaries. NDDC built six blocks of classrooms, tarred a road, provided pipe-borne water and rural electrification projects in Gelegele. It constructed six blocks of classrooms in Oben, a primary school and health centre in Ologbo and provided health centre, water scheme and rural electrification project in Ughoton. However, field observation showed that the NDDC had no presence in Iguelaba. EDSOGPADEC, on the other hand, constructed a secondary school in Gelegele, renovated Ozolua Grammar School in Ologbo, sunk borehole in Iguelaba and Oben. In the area of human capital development, EDSOGPADEC distributed motorbikes to youths in Oben and Gelegele. It provided skill acquisition training for a number of women in fashion design and hairdressing. It also constructed blocks of flat for teachers and health workers in the rural communities. Similarly, it tarred about $30 \mathrm{~km}$ of road $-10 \mathrm{~km}$ each in the three oil-bearing local government areas of the state: Orhionmwon, Ikpoba-Okha and Ovia North East.

Nevertheless, both agencies have attracted criticisms. Oshodin (personal communication, October 2, 2015) argued that official corruption, political interference and mismanagement of funds were some of the greatest impediments facing these oil commissions. They have also been criticized for not being community-oriented, serving basically the interests of active stakeholders, such as politicians, government officials, board members, high-ranking staff members of the commissions, and a few traditional rulers/community leaders, contractors and consultants. It was argued that conception, planning and implementation of community development projects did not adequately involve objective, all-inclusive and sincere needs assessment or local community inputs. Rather, it was always characterized by lack of transparency and a tendency to allocate resources to satisfy only those active stakeholders. These individuals influence the location of development projects; and, in some cases, projects are cited in non-oil communities to compensate "friends of the government".

The NDDC, in particular, has been accused of paying less attention to human capital development and over-politicization of projects, as successive managements award new contracts instead of completing existing ones. That is why the region is littered with several abandoned projects. The few completed projects lack quality. These projects face sustainability issues, as they were largely executed with little or no consideration for their end use or sustenance (personal communication, September 25, 2015). Furthermore, the NDDC lacks visible presence in the oil-bearing areas of Edo State perhaps because the state is located at the periphery in terms of oil production in the Niger Delta. The commission appears to have concentrated its interventions on the core Niger Delta States where the conflicts are perceived to constitute greater challenge to economic stability and national security. However, as Tokunbo (personal communica- 
tion, September 30, 2015) argued, though more preponderant in the core oil-bearing states, challenges that naturally flow with oil companies' exploitative activities being the same everywhere and also constitute a threat in peace in the oil-bearing areas of Edo State.

\section{Conclusion:}

\section{Imperative of Conflict Transformation}

Low-intensity conflicts induced by oil exploitation in Edo State have the potential to transit into high-intensity conflicts. Although the various conflict management strategies adopted have been able to douse tension and prevent conflict escalation, they have largely remained ineffective as mechanisms for conflict transformation mainly due to inadequate engagement, lack of transparency, and the absence of a participatory approach to conflict management. Conflict transformation requires addressing the underlying causes of the conflict and building long-standing relationship through a process of change in perception and attitude of stakeholders. What the oil-bearing communities need is development. Beyond remediation of the environment, these communities have yearned for infrastructural and human capital development which has remained elusive. Addressing these key community demands requires adequate engagement and active local community participation in the community development and peacebuilding initiatives of the government and oil companies.

Furthermore, the pathway to building long-standing stakeholder relationship and sustainable peace must be community-centred. It must take into consideration the need for socioeconomic empowerment and justice for the oil-bearing community. Experiences in the Niger Delta showed that mismanagement of local community agitations, perceived neglect, marginalization, and exclusion of these communities from the oil-industry were largely responsible for transformation of the conflicts and subsequent militarization of the region. Thus, paying weak attention to the frustration and grievances of the oil-bearing communities can lead to conflict escalation, which would inadvertently contribute to the already heightened insecurity situation in the Niger Delta area.

\section{References:}

1. Adeosun, A. B., Norafidah I., \& Knocks, T. Z. (2016). Elites and Conflict in Nigeria: A Case Study of the Niger Delta Insurgency. International Journal of Political Science and Development, 4(8), 301-314.

2. Aiyede, R. E. (2006). The Case of Oil Exploitation in Nigeria. In I. K. Richter, S. Berking and R. Muller-Schmid (Eds.). Risk Society and the Culture of Precaution. New York: Palgrave Macmillan, 131-146.

3. Bassey, O. C. (2012). Oil and Conflict in the Niger Delta: A Reflection on the Politics of State Response to Armed Militancy in Nigeria. Mediterranean Journal of Social Sciences, 3, 77-91. 
4. Carr, H. H., \& Snyder, A. C. (2002). The Management of Telecommunications. Irwin: McGraw Hill College.

5. Clark, V. E. (2016). The Politics of Oil in Nigeria: Transparency and Accountability for Sustainable Development in the Niger Delta. American International Journal of Contemporary Research, 6(4), 76-82.

6. Collier, P., \& Hoeffler, A. (2004). Greed and Grievance in Civil War. Oxford Economic Papers, 56, 563-595.

7. Cornwall, A. (2006). Beneficiary, Consumer, Citizen: Perspective on Participation for Poverty Reduction. Sidastuden, No. 2.

8. Debraj, R., \& Esteban J. (2017). Conflict and Development. Annual Review of Economics, 9, 263-293.

9. Emuedo, O. C. (2015). Oil Multinationals and Conflict Construction in Oil-host Communities in the Niger Delta. African Journal of Political Science and International Relations, 9(5), 170-180.

10. Faleti, S. A. (2010). Corporate Social Responsibility Initiatives of Selected Multinational Companies in the Niger Delta, Nigeria. PhD Dissertation presented at the Institute of African Studies, University of Ibadan.

11. Human Rights Watch. (1999). The Price of Oil: Corporate Responsibility and Human Rights Violations in Nigeria's Oil Producing Communities. London: HRW.

12. Ibeanu, O. (2000). Oiling the Friction: Environmental Conflict Management in the Niger Delta, Nigeria. Environmental Change and Security Project Report, Issue 6. Washington DC.: The Woodrow Wilson Centre.

13. Idemudia U. (2011). Corporate Social Responsibility and the Niger Delta Conflict: Issues and Prospects. In O. Cyril and S. A. Rustad (Eds.), Oil and Insurgency in the Niger Delta, Managing the Complex Politics of Petro-Violence (pp. 167-183). London: Zed Books.

14. Idemudia, U. (2009a). Assessing Corporate-Community Involvement Strategies in the Nigerian Oil Industry: An Empirical Analysis. Resource Policy, 34(3), 133-141.

15. Idemudia, U. (2009b). Oil Extraction and Poverty Reduction in the Niger Delta: A Critical Examination of Partnership Initiatives. Journal of Business Ethics, 90, 91-116.

16. Ikelegbe, A. (2005). The Economy of Conflict in the Oil Rich Niger Delta Region of Nigeria. Nordic Journal of African Studies, 14(2), 208-234.

17. Ikelegbe, A., \& Umukoro, N. (2014). Exclusion and the Challenges of Peace Building in the Niger Delta: An Assessment of the Amnesty Programme. Benin City: CPED Monograph Series, No. 11.

18. Joab-Peterside, S., Porter, D., \& Watts, M. (2012). Rethinking Conflict in the Niger Delta: Understanding Conflict Dynamics, Justice and Security. Niger Delta Economies of Violence, Working Paper No. 26.

19. Lederach, J. P. (1997). Building Peace: Sustainable Reconciliation in Divided Societies. Washington, D.C.: United States Institute of Peace Press.

20. Newsom, C. (2011). Conflict in the Niger Delta: More than a Local Affair. Special Report. Washington D.C.: United State Institute of Peace. 
21. Okoh, N. R. (2005). Conflict Management in the Niger Delta Region of Nigeria: A Participatory Approach. African Journal on Conflict Resolution, 5(1), 91-114.

22. Paffenholz, T. (2009). Understanding Peacebuilding Theory: Management, Resolution and Transformation. Journal of Peace Research and Action, 14(2), 3-7.

23. Sayne, A. (2013). What's Next for Security in the Niger Delta? Special Report. Washington D.C.: United States Institute of Peace.

24. Shebbs, U. E., \& Njoku, R. (2016). Resource Control in Nigeria- Issues of Politics, Conflict and Legality as Challenge to Development of the Niger Delta Region. Journal of Good Governance and Sustainable Development in Africa, 3(3), 32-45.

25. Siollun, M. (2009). Oil, Politics and Violence: Nigeria's Military Coup Culture (19661976). New York: Algora Publishing.

26. Traub-Merz, R. (2004). Introduction. In R. Traub-Merz and D. Yates. (eds.), Oil Policy in the Gulf of Guinea: Security and Conflict, Economic Growth, Social Development. Bonn, Germany: Friedrich-Ebert Stiftung, 9-22.

27. Watts, J. M. (2004). Antimonies of Community: Some Thoughts on Geography, Resources and Empire. Transactions of the Institute of British Geographers, 29, 195-216. 